\title{
Leaf litter processing in low order streams
}

\author{
Manuel A. S. Graça \& Cristina Canhoto \\ Departamento de Zoologia, Universidade de Coimbra, 3004-517 Coimbra, Portugal \\ mgraca@ci.uc.pt; ccanhoto@ci.uc.pt
}

\begin{abstract}
Forests produce a large amount of detritus, that inevitably end up in streams, subsidizing aquatic systems with organic matter and nutrients. Here we review some of the research carried out at the University of Coimbra with the objective of getting a better understanding of the breakdown process of these materials and its incorporation to secondary production. Litter-fall in deciduous forests in Central Portugal can reach up to $750 \mathrm{~g} \mathrm{AFDM}$ of leaves $\mathrm{m}^{-2} \mathrm{yr}^{-1}$, with $73 \%$ of the litter produced between October and December. In several retention experiments, we measured a $90 \%$ leaf retention in low order $\left(1^{\text {st }}-4^{\text {th }}\right)$ streams within $15-70 \mathrm{~m}$, and a standing stock of up to $450 \mathrm{~g} \mathrm{AFDM} \mathrm{m}^{-2}$. The amount of nutrients in the water and the plant physical and chemical defenses can be an indicator of the rate at which plant material is incorporated into secondary production or exported as dissolved and fine particles of organic matter. Respiration rates of decomposing leaves incubated with fungicides were severely reduced, supporting the idea that fungi are very important agents in litter breakdown. The fungi group known as aquatic hyphomycetes are capable of producing enzymes able to cause leaf maceration, and by 2 to 3 weeks, up to $15 \%$ of the decomposing leaf biomass corresponds to fungi. Shredder invertebrates are also biological agents involved in litter breakdown. Given their densities and feeding rates, we measured consumption rates of $12-54 \mathrm{~g}$ of leaves $\mathrm{m}^{-2} \mathrm{yr}^{-1}$ in a stream in Central Portugal, corresponding to 2 to 9 times the litter standing stock. Feeding rates were high in nutrient rich leaves and low in chemical and physically protected leaves with low nutrient content. According to several experiments, fungal colonization facilitates the access of invertebrates to the energy trapped in deciduous leaves in streams. Some invertebrates have strategies to cope with low quality food (leaves with low microbial biomass or high chemical defenses). Those include high mobility, small size, compartmentalized digestion in the gut, presence of endosymbionts, and the capability to decrease respiration rates. The relative importance of fungi and invertebrates in the incorporation of plant litter material into secondary production varies across rivers and biomes. Shredder invertebrates seem to play a key role in litter breakdown in headwaters, but their importance appears to decrease downstream. In the same way, some systems where leaves are hard or protected, shredder invertebrates may be less abundant and the energy may be mainly recovered from litter by fungi. Eucalyptus plantations are systems with low diversity of invertebrates and aquatic hyphomycetes. Streams running through eucalyptus plantations seem therefore ideal to experimentally investigate relationships between structural parameters (biodiversity) and function. Finally, our research has been extended to other climatic areas including the Mediterranean and tropical streams. We reported a wide variety of situation in those systems. A general rule applying to all of them is that if leaf litter is abundant and high quality, the incorporation of energy into detrital food webs can be processed very quickly. However, if leaves are well protected and nutrients in the water are low, processing rates are equally very low, independently of the ambient temperatures.
\end{abstract}

Key words: litter balance, decomposition, fungi, detritivores, Mediterranean and tropical streams.

\section{RESUMEN}

Los bosques producen una gran cantidad de detritus orgánicos, que inevitablemente llegan a los ríos, subsidiando los sistemas acuáticos con materiales y nutrientes. Aquí se revisan algunos de los trabajos que se han hecho en la Universidad de Coimbra con el objetivo de entender mejor el proceso de descomposición de este material y su incorporación en producción secundaria. La entrada de hojarasca en bosques caducifolios del Centro de Portugal puede alcanzar hasta $750 \mathrm{~g}$ PSLC (peso seco libre de cenizas) $m^{-2}$ año ${ }^{-1}$, con $73 \%$ de este valor ocurriendo entre Octubre y Diciembre. En varios experimentos de retención medimos que cerca de $90 \%$ hojas que entran en rios de baja orden $\left(1^{a}-4^{a}\right)$ eran retenidas entre los 15 y 75 m, y que

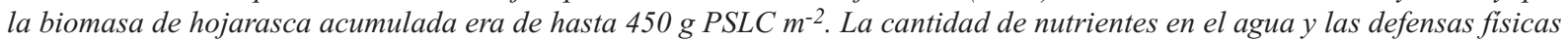
y químicas de las plantas pueden ser un indicador de la tasa a que el material orgánico es incorporado en producción secundaria o exportado como material disuelto o finamente particulado. Las tasas de respiración de hojas incubadas con fungicidas disminuyeron severamente apoyando la idea de que los hongos son agentes muy importantes en la descomposición de hojarasca el los ríos. El grupo de hongos conocido como hifomicetos acuáticos producen enzimas que causan la maceración de hojas, y en 2 o 3 semanas, hasta $15 \%$ de la biomasa de una hoja en descomposición puede corresponder a hongos. Los invertebrados desmenuzadores son también agentes biológicos en la descomposición. Dadas las densidades de desmenuzado- 
res y sus tasas de ingestión de alimento, hemos calculado tasas de consumo de hojas en ríos de $12-54 \mathrm{~g} \mathrm{~m}^{-2}$ año-1 lo que corresponde a 2 a 9 veces la cantidad de hojarasca presente. Las tasas de consumo son generalmente altas en substratos ricos en nutrientes y bajas en hojas pobres en nutrientes o protegidas del punto de vista químico y físico. De acuerdo varios experimentos, la colonización por hongos facilita el acceso de los invertebrados a la energía de las hojas. Algunos invertebrados han desarrollado estrategias para poder vencer la baja calidad de las hojas, incluyendo un alta movilidad, tamaño pequeño, compartimentalización de la digestión en el intestino, presencia de endosimbiontes y la capacidad para disminuir las tasas respiratorias. La importancia relativa de los hongos e invertebrados en la incorporación de la hojarasca en producción secundaria es variable entre ríos y biomas. Los invertebrados desmenuzadores parecen jugar un papel importante en la descomposición de hojarasca en los ríos de bajo orden, pero su importancia parece disminuir rió abajo. Del mismo modo, en algunos sistemas en que las hojas son duras o protegidas, los invertebrados pueden ser menos abundantes y la energía canalizada en producción secundaria principalmente por los hongos. Las plantaciones de eucaliptos son sistemas con una baja diversidad de invertebrados e hifomicetos acuáticos. Los ríos que corren por plantaciones de eucaliptos parecen ser por este motivo sistemas ideales para investigar las relaciones entre parámetros estructurales (biodiversidad) y función. Finalmente, nuestra investigación ha sido extendida para otras zonas climáticas, incluyendo el Mediterráneo y las zonas tropicales. Hemos reportado una gran variedad de situaciones en esos sistemas. Una regla general a todos ellos es que si la hojarasca es abundante y de alta calidad, la incorporación de la energía de las hojas en las cadenas alimentares se procesa de forma muy rápida. Sin embargo, si las hojas están bien protegidas y los nutrientes el agua son bajos, estas tasas son igualmente muy bajas, independientemente de las temperaturas ambientales.

Palabras clave: Balance de la hojarasca, descomposición, hongos, detritívoros, arroyos mediterráneos y tropicales.

\section{ALHOCHTHONOUS ORGANIC MATTER IS AN IMPORTANT ENERGY SOURCE FOR FORESTED LOW ORDER STREAMS}

Forests are among the most productive systems on Earth with primary production reaching $1800 \mathrm{~g}^{\text {dry }}$ mass $^{-2}$ year $^{-1}$ in the tropics. Even boreal forests are more productive than cultivated lands ( 850 vs. $750 \mathrm{~g}$ dry mass $\mathrm{m}^{-2}$ year ${ }^{-1}$, respectively; Ricklefs, 2000). In forested systems less than $5 \%$ of the primary production will be lost to herbivores (Ricklefs, 2000); this implies that a very large proportion of the energy fixed in forests will end in the detrital pathways (Fig. 1). This is particularly evident in deciduous forests with litter-fall ranging from 300 to $800 \mathrm{~g}$ dry mass $\mathrm{m}^{-2}$ year-1, or with $>1000 \mathrm{~g}$ dry mass $\mathrm{m}^{-2}$ year $^{-1}$ in tropical forests (reviewed Abelho, 2001).

With such an amount of litter production, it is virtually impossible that leaves, fruits, seeds, twigs, and other plant remains, will not end in streams. Moreover, trees in the riparian zones shade the small streams, decreasing in this way the amount of solar energy which could be used by primary producers. Therefore, litter shed by trees is likely to be a key energy source for low order streams running through forests. It is therefore ecologically relevant to understand the fate of energy and nutrients in those systems. At the University of Coimbra, Portugal, we have been addressing several aspects of litter decay in small streams for the last 15 years. Here we review the main findings of our research.

\section{LITTERFALL AND THE DYNAMICS OF ORGANIC MATTER}

How are leaves retained in streams? Can we predict decomposition rates of leaves based on their intrinsic characteristics? What is the relative role of the environment in litter decomposition? What are the main agents affecting litter decomposition? To address some of those questions we began measuring litter dynamics in deciduous forests in Central Portugal. In a forest dominated by Castanea sativa Mill., annual litter-fall reached $750 \mathrm{~g} \mathrm{~m}^{-2} \mathrm{yr}^{-1}$, with $73 \%$ of litter produced between October and December, which is consistent with other results reported for deciduous forests. Nearly $90 \%$ of the leaves falling into low order streams in Central Portugal were retained in within $10-70$ meters, with retention decreasing downstream (Canhoto \& Graça, 1998). Retained litter accumulates in the stream-bed before being processed or washed away during floods; we measured standing 
stocks of organic matter of $50-450$ g AFDM $\mathrm{m}^{-2}$ in streams of central Portugal. These values were much higher than the standing stock of periphyton $\left(6 \mathrm{~g} \mathrm{~m}^{-2}\right.$; Abelho \& Graça, 1998) in the same river. Moreover the amounts of coarse particulate organic matter in rivers tend to decrease downstream, whereas the standing stocks of benthic algae tend to increase in the same direction (Cortes et al., 1995).

Decomposition is therefore a critical ecosystem process, determining the availability of nutrients for primary producers. Can we predict the rate at which leaves decompose? The answer, to some extent, is yes. We found that decomposition rates increase with nitrogen content of leaves and decrease with the amount of plant chemical and physical defenses (Cortes et al., 1994; Canhoto \& Graça, 1996). Decomposition rates also tend to increase with nutrient content in the water. This information is important for conservation, restoration and management of riparian zones. "Cleaning" streams by removing wood and other retentive features and removing stream-shading vegetation is a bad environmental practice. Although litter decomposition proceeds until all material is mineralized, this paper will refer to the breakdown of large particles of organic matter and not to the processing of fine particles or dissolved organic matter.

\section{DECOMPOSERS}

When leaves enter the streams, their nitrogen content generally increases. This is evidence of microbial colonization, which can be corroborated by the increase of ATP and oxygen consumption of leaves (Abelho et al., 2005). Moreover, leaves start loosing mass at a rate proportional to microbial colonization (Suberkropp \& Chauvet, 1995); decomposition is therefore a biological process and a measurement of the rate of incorporation of leaf material into secondary production.

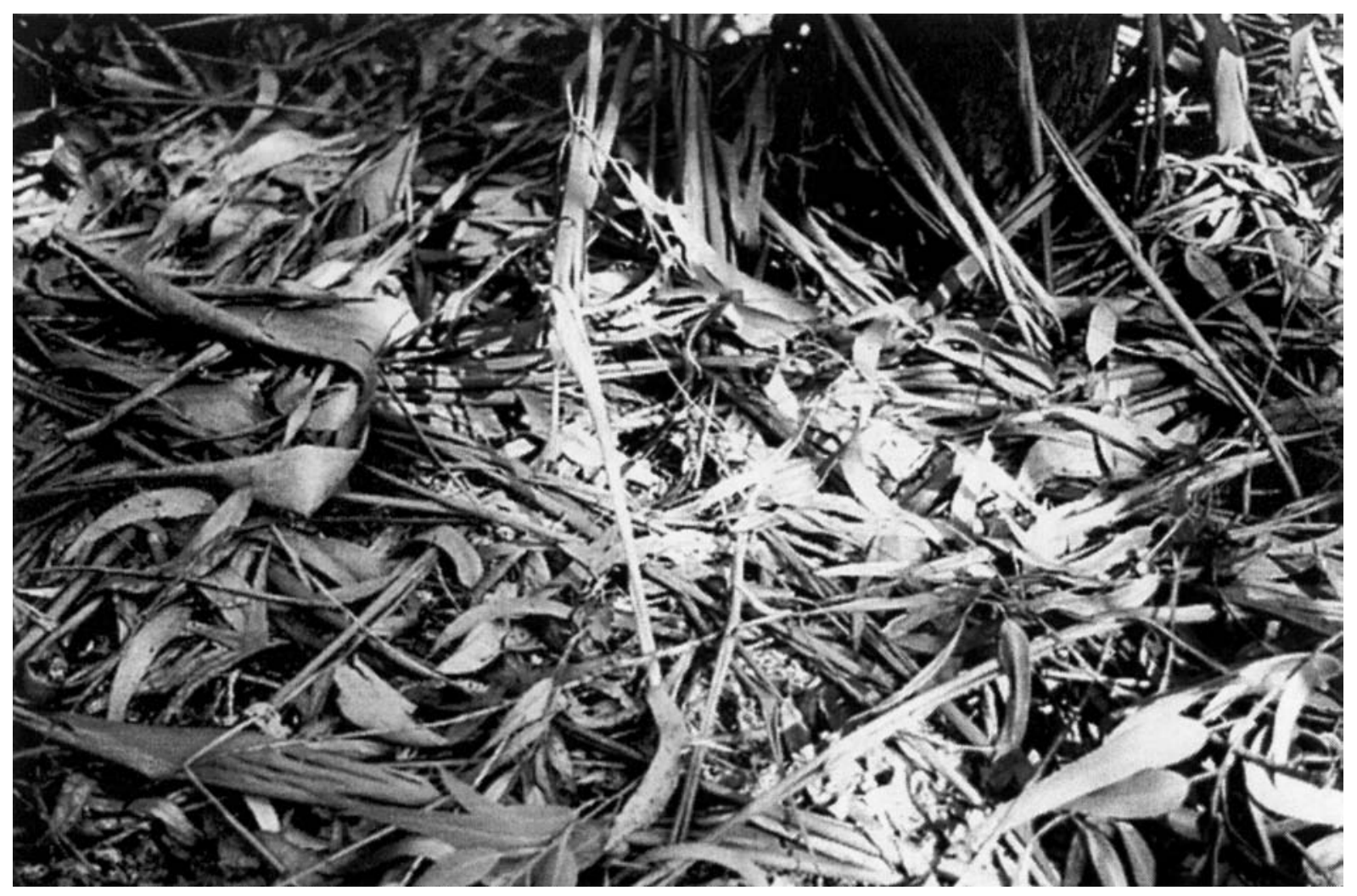

Figure 1. Leaf litter accumulated on soil in a Eucalyptus plantation. Hojarasca acumulada en el suelo de una plantación de Eucaliptus. 
Which are the microorganisms involved in litter decomposition? There is evidence from the literature, that fungi are more important than bacteria in this process in terms of biomass and production (e.g. Pascoal \& Cassio, 2004; Abelho et al. 2005). In a tropical stream, we found that leaves exposed to fungicides had lower respiration rates and lower microbial biomass than leaves exposed to bactericides. Other authors concluded that even under organic pollution conditions, production of bacteria in leaves is lower than fungal production (Pascoal \& Cassio, 2004).

It is also generally accepted that fungal decomposers of leaves are aquatic hyphomycetes (Fig. 2; Gessner \& Chauvet, 1994; Gulis \& Suberkropp, 2003), since just after submersion a large amount of conidia start detaching from leaves (e.g. Bärlocher, 2000). However, many geofungi have been also isolated from decomposing submersed leaves plated over agar. What is the relative role of both types of decomposers in the decomposition of organic matter in streams? To answer this question we measured the capability of several species of geofungi and aquatic hyphomycetes to cause leaf maceration in water and under laboratory conditions. Only aquatic hyphomycetes caused significant leaf maceration (measured as mass loss and decrease in tensile strength) and had higher enzymatic (xylanase, pectinlyase and polygalacturonase cellulose $\mathrm{C} 1$ and $\mathrm{Cx}$ ) activity in submerged substrates than terrestrial fungi isolated from leaves (Graça \& Ferreira, 1995; Rodrigues \& Graça, 1997). Softening was correlated with the activity of all enzymes, especially xylanase $\left(\mathrm{r}_{\mathrm{s}}=0.94 ; \mathrm{P}<0.001\right)$.

Our conclusion is that when falling in the water, leaves are already colonized by terrestrial fungi, but their activity is severely depressed. In the water, leaves are rapidly exposed to thousands of spores of aquatic hyphomycetes (e.g. Bärlocher \& Graça, 2002) that germinate and grow into the leaf substrates (Canhoto \& Graça, 1999) and produce degrading enzymes (Canhoto et al., 2002).

Many of the chemical and physical plant defenses against pathogens and herbivores may remain active after senescence. Thick cuticles may have a two-fold role in plants, by decreasing water losses and retarding fungal attack. One of the explanations for the lower decomposition rates of some eucalyptus leaves in nutrient poor streams is the presence of a thick cuticle. Electronic microscopy observations showed that fungi can only penetrate into the leaf mesophyll of eucalyptus leaves through stomata and cracks at the waxy cuticle (Canhoto \& Graça, 1999).

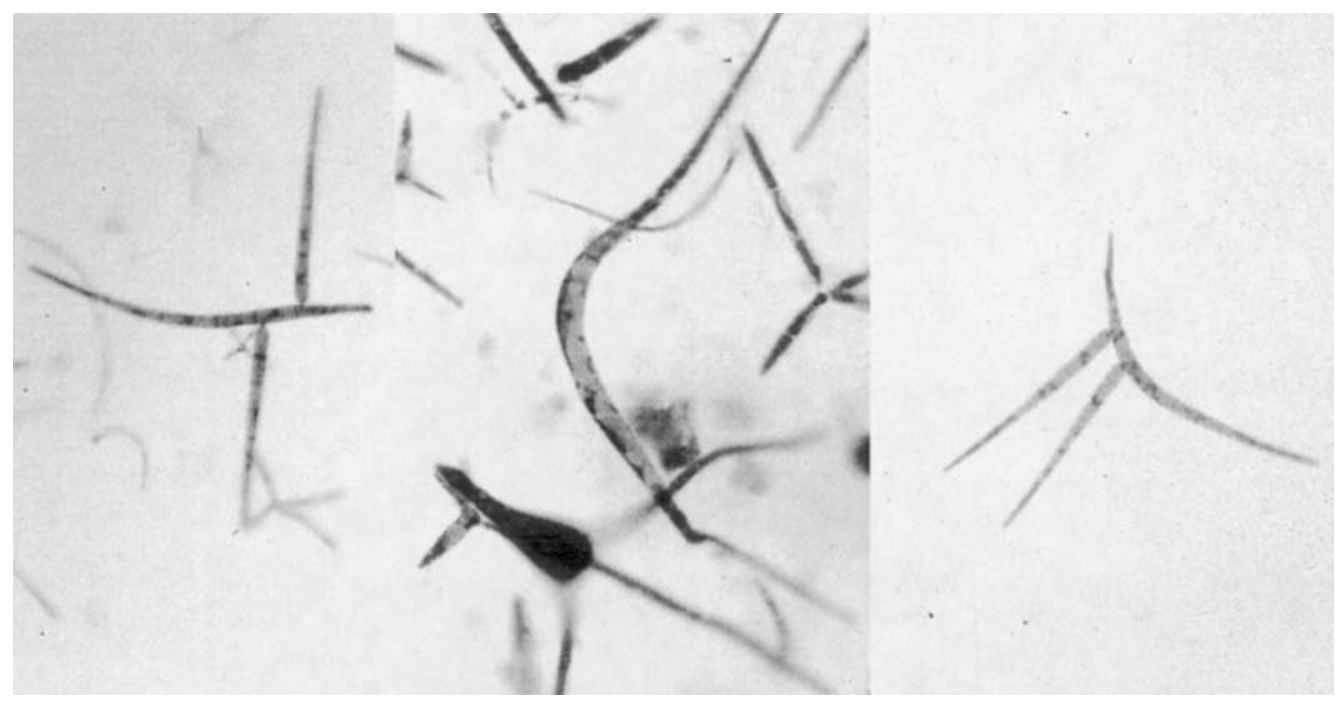

Figure 2. Spores of aquatic hyphomicetes: left and right: Tricladium splendens; center: Clavariopsis aquatica, Articulospora tetracladia and a sigmoid. (Photos by Felix Bärlocher). Esporas de hifomicetes acuáticos: izquierda y derecha: Tricladium splendens; centro: Clavariopsis aquatica, Articulospora tetracladia y un sigmoide (Fotos de Felix Bärlocher). 
Another defense of eucalyptus leaves is the presence of oils, allocated in glands. In eucalyptus leaves, oils may account for up to $5 \%$ of leaf mass (Canhoto \& Graça, 1999) and they are known to be have antibiotic properties. They were found to also reduce or suppress growth of aquatic hyphomycetes in vitro (Canhoto \& Graça, 1999) and interfere with microbial enzymes (Canhoto et al., 2002). Fungal sporulation from eucalyptus leaves was retarded when compared with other leaves, but the removal of cuticle and oils resulted in accelerated sporulation (Canhoto \& Graça, 1996; Bärlocher et al., 1995). The extraction of oils from eucalyptus leaves also resulted in an increase of consumption by the shredder Tipula lateralis, whereas the transference of eucalyptus oils to alder leaves resulted in a decrease in food consumption by the same shredder.

\section{DETRITIVORES}

Many stream invertebrates use leaf litter as a food resource. Besides incorporating leaf material into secondary production, shredder invertebrates fragment leaves and produce a large quantity of fecal pellets. The result is the transformation of coarse particulate organic matter (C.P.O.M.) into fine particulate organic matter (F.P.O.M.), which may constitute an important food source for other organisms we call "deposit feeders" and "filter feeders".

Feio \& Graça (2000), González \& Graça (2003), and Azevedo-Pereira et al. (2006) calculated for a mountain stream in Central Portugal that the mean annual consumption of leaves by the caddisflies (Sericostoma vittatum Rambur and Lepidostoma hirtum (Fabricius)) was, respectively, $12-22 \mathrm{~g} \mathrm{~m}^{-2}$ year-1 $^{-1}$ and 54 $\mathrm{g} \mathrm{m}^{-2}$ year $^{-1}$. These values correspond to $2-9$ times the leaf standing stock of the stream. Shredder invertebrates have therefore a key role in the trophic ecology of low order streams (reviewed Graça 1993, 2001).

Several factors can constrain the access of invertebrates to the energy trapped in leaves. To start with, a reduced number of animals have the enzymatic capability to use the structural compounds of leaves. How do they manage to access the plant energy? We have been studying energy transference from litter pool to invertebrate shredders, using the caddisflies Sericostoma vittatum Rambur, and Lepidostoma hirtum (Fabricius), as well as the crane fly Tipula lateralis Meigen (Fig. 3) as test organisms. Leaves differ in their quality for shredders as asserted from measurements of feeding rates, food choice experiments and growth rates (e.g. González \& Graça, 2003). The incorporation of leaf material into invertebrate secondary production proceeds at a faster rate in nitrogen rich and soft leaves, when compared with nitrogen poor, chemically protected, hard leaves (Canhoto \& Graça, 1995; González \& Graça, 2003). The implication is that changes in the frequency of leaf types and therefore forest practices may affect the dynamics of invertebrates in streams. Moreover, litter-fall in temperate areas occurs mainly during autumn, and litter is composed by a mixture of leaves differing in their quality. Leaves of high quality such as alder are quickly consumed, whereas leaves of more recalcitrant species, such as oak, take longer time to be fully colonized and degraded by microorganisms, but they can be a good resource for later in the season. If the mixture of leaves is replaced exclusively by leaves of high quality, it may supply shredders with a large input of high quality food for a short period of time, but energy may lack in later stages. On the other hand, if streams are provided only with low quality resources, food may be scarce early in the season.

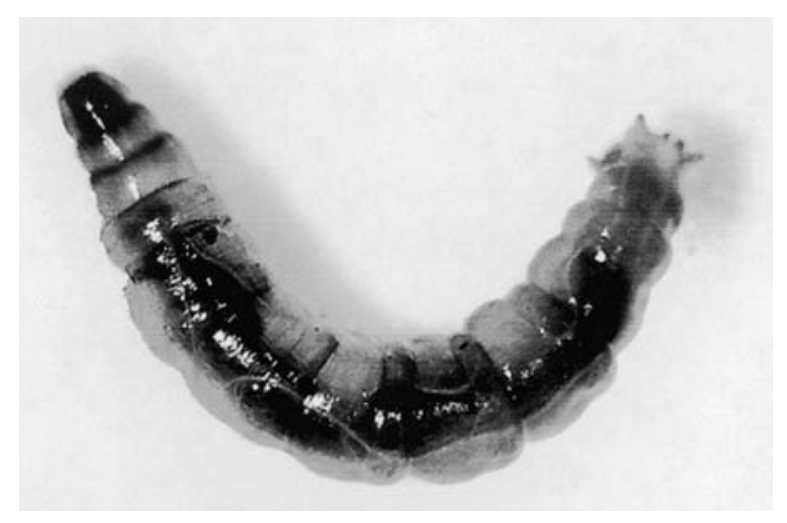

Figure 3. Larvae of Tipula lateralis, a stream shredder. Larva de Tipula lateralis, un triturador fluvial. 


\section{INTERACTIONS BETWEEN DETRITIVORES AND FUNGI}

One common observation on the ecology of shredder detritivores is that they preferentially feed on fungal colonized leaves in laboratory (Suberkropp, 1992; Graça et al., 1993b) and field conditions (Graça, 1992). They also feed and grow faster, survive better and have a larger reproductive output when leaves are fully colonized by fongi (Graça et al., 1993b). The reason seems clear: fungal colonization cause leaves to increase nitrogen content (because of fungal biomass) and leaf maceration, benefiting in this way from microbial enzymes (Suberkropp, 1992; Graça et al., 1993b; Graça, 1993). Some shredders do selectively consume the leaf patches with high fungal mass or selectively feed on fungal biomass growing on the surface of the leaves (e.g. Graça et al., 1993b; Graça et al., 2000).

\section{SOME NOTES ON THE ECOLOGY OF SHREDDERS}

Fast moving invertebrates are very active visiting patches were litter accumulates and probably remaining for short periods of time in the patches if the food quality is low. For invertebrates with low mobility, high selectivity may not be an option because if they reject less-profitable food they may spend a long time searching before they encounter food again. Invertebrates with low mobility may be more efficient in taking their energetic requirements from low quality food.

Tipulidae larvae are slow moving invertebrates that inhabit streams. Unlike carnivore tipulids, shredder tipulids have an alkaline anterior gut with a pH $10.5-11$ (e.g. Bärlocher \& Porter, 1986; Graça \& Bärlocher, 1998; Canhoto, 2001). At such a high $\mathrm{pH}$, the gut proteolytic activity of these tipulids remain active and is not affected by polyphenolics from leaf extracts (Graça \& Bärlocher, 1998). This strategy therefore, allows for a maximum protein extraction and, at the same time, the plant defenses are overcome. In the posterior section of these tipulids gut, $\mathrm{pH}$ values are neutral/alcaline and a high number of endosymbionts seem to have a key role in the digestion of the plant polysaccharides.

In a series of laboratory experiments, we found that Gammarus pulex (L.) was able to maintain growth even when low quality food was supplied whereas that did not happen with the less active Asellus aquaticus L. (Graça et al., 1993a). G. pulex compensated for low quality food by reductions in respiration rates. Although another form of compensation may be the increase of food intake to maintain a constant energy / nutrient income (e.g. Calow, 1975; Rollo \& Hawryluk, 1988), in most cases, shredding invertebrates decrease their energy intake when fed low quality food.

\section{WHAT IS THE RELATIVE IMPORTANCE OF INVERTEBRATES AND FUNGI IN THE INCORPORATION OF LEAF ENERGY INTO FOOD WEBS?}

The relative importance of invertebrates and fungi in litter breakdown, and therefore in the incorporation of energy trapped in leaf tissues into food webs has been a matter of debate (see references in Graça, 2001). Apparently, whereas fungi are omnipresent in all flowing waters, the densities of shredder invertebrates can be controlled by other factors, including the quality and quantity of the litter. Therefore, in some systems invertebrates can be considered as unimportant in energy transference in detritus based systems, while in other cases they may be the key elements. For example, Hiebber \& Gessner (2002) calculated that, in a stream, fungi were responsible for removing $15-18 \%$ of leaf mass, whereas the values for shredder invertebrates were $51-64 \%$. On the other hand, Gonçalves et al. (2006) calculated that almost no litter energy in the form of coarse particulate organic matter was taken into secondary production by invertebrates due to the high recalcitrant properties of Savannah Cerrado streams.

As the availability of coarse particulate organic matter tends to decrease downstream and nutrients in the water to increase in the same 


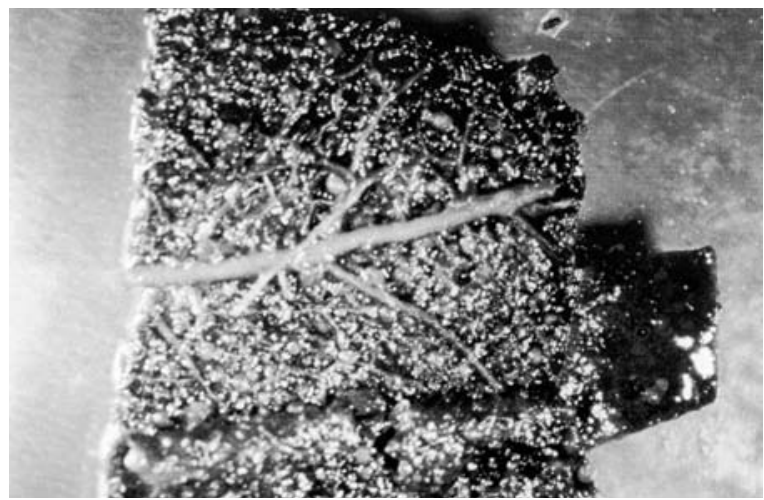

Figure 4. Eucalyptus leaf with oil glands in white. Hoja de eucalipto con las vesículas de aceite en blanco.

direction, it is plausible that the role of both types of organisms change along the longitudinal gradient. We tested this hypothesis in a series of streams, ranging from $2^{\text {nd }}$ to $6^{\text {th }}$ order in Central Portugal. Decomposition rates did not differ along the longitudinal gradient (see also Cortes et al., 1995). However, microbial role on litter decomposition increased downstream as judged by the difference in mass loss in leaves incubated in coarse and fine mesh bags. Consistently, the density in spores in the water column increased downstream, whereas the density and percentage of shredder invertebrates increased upstream. This relationship was observed only in spring / summer. It is conceivable that during autumn / winter there might be a surplus of energy in the form of leaves and the impact of invertebrate feeding on litter breakdown may then be small (Graça et al., 2001b).

\section{STRUCTURAL AND FUNCTIONAL PARAMETERS IN DETRITUS BASED SYSTEMS}

Detritus based systems are a ground for testing some ecological theories. For instance, species replacement has been analyzed from the structural point of view but we can learn a lot on the functional changes related to species replacement by invasions. Species invasions have shown to affect community structure, sometimes with the reduction of biodiversity due to local extinctions and the dominance of introduced species (Towsend et al., 2000). Given that decomposition is controlled by nutrient related factors and plant defenses, can we predict the ecological effects of species introductions?

If the plant invader is a nitrogen fixing species, then we may expect that the turn over of organic matter to be accelerated. However, if the invaders are chemically or physically protected, decomposition and therefore the rate at which energy re-enters the biota component of ecosystems to be retarded. Invaders are very common in riparian areas (e.g. Vitousek, 1996) and we have been testing these assumptions by looking at soil and aquatic systems.

In a series of litter breakdown experiments in which introduced $v s$. native and high quality ( $\mathrm{N}$ content) vs. low quality (high protection) leaves in soils and water were compared, it was found that decomposition rates and associated processes such as microbial and invertebrate colonization were independent of plant origin, but could be explained by intrinsic leaf proprieties (Pinto et al., 1997; Pereira et al., 1998).

In aquatic systems we compared streams bordered by native deciduous and eucalyptus plantations. Eucalyptus are originally from Australia, but they are nowadays ubiquitous in several parts of the world. Vast areas in the Iberian Peninsula are planted with eucalyptus. This subject was reviewed by Graça et al. (2002) and will not be treated in detail here, but we can summarize the changes associated to eucalyptus plantations in the following way:

In eucalyptus plantations the seasonality of litter-fall is altered from an autumn peak to an even litter-fall along the year or a summer peak if the hydrological stress is high. The average standing stock of organic matter was not different between native deciduous and eucalyptus plantations; streams or tended to be higher in eucalyptus plantations, probably because of spates and bark accumulation, which increases litter retention. Fungi accumulate in decomposing leaves at similar rates in both stream types. Eucalyptus leaves are a low quality substrate for shredder invertebrates and fungi, as judged from: (a) their oil content with antibiotic proper- 
ties (Fig. 4), affecting fungal growth, fungal digestive enzyme activity (Canhoto et al., 2002), and (b) feeding experiments with invertebrates in which there was a decrease in surviving, growth and feeding rates when fed with eucalyptus leaves. Oils inhibit fungal growth and invertebrate consumption in vitro (Canhoto \& Graça, 1999). Elimination of leaf lipids resulted in faster decomposition and high sporulation by aquatic hyphomycetes (Bärlocher et al., 1995).

Maybe for those reasons, invertebrate and fungal richness was low in Portuguese streams running through eucalyptus plantations. Because assemblages of decomposer and detritivore species are poor in eucalyptus streams, we have an ideal model system to investigate relationships between community structure and ecosystem functioning. For instance, Bärlocher \& Graça (2002) reported that although streams running through eucalyptus forests had lower number of aquatic hyphomycete species, decomposition rates of chestnut (Castanea sativa) were similar (but see Abelho \& Graça, 1998).

\section{TROPICAL SYSTEMS}

The ecology of low order streams is well established for temperate areas, but scarce in other zones. Most of the literature on the dynamics of litter-fall and the fate of organic matter entering streams is based on research carried out in North America and Europe. A quick survey in the "Web of Science" was run for citations on papers dealing with litter breakdown in streams from 2000 to 2004 and 110 references were found, $44 \%$ from North America, $30 \%$ from Europe, $8 \%$ from the Mediterranean, $8 \%$ from Australia and New Zealand and $2 \%$ for the rest of the world, revealing that patterns of litter dynamics in forested stream systems are based upon research carried out in a restricted geographic area. Do the reported patterns apply to areas with different productivity, seasonality and hydrology? Do invertebrates and microbes play a similar role in other climates?

In a series of feeding trials we found that, as reported for tempered shredder species, tropical shredders also selectively feed on microbial colonized leaves, and there was a tendency for growth rates to be reduced in the absence of microbial assemblages in the leaves. The rate at which leaves are incorporated into secondary production was more variable in the tropical areas than in temperate ones. In experiments carried out in tropical cloudy forests in Venezuela, decomposition rates were fast, with $50 \%$ of leaf mass loss in less than 10 days in leaves of Hura crepitas L. The leaves of this species were found to be equivalent to those of Alnus glutinosa (L.) in terms of food resources and decomposition rates (Graça et al., 2001a and unpublished data). However, in Savannah streams, in Brazil (Cerrado), it took 90 days for alder leaves to loose $50 \%$ of their mass (Gonçalves et al., 2006). Apparently, the availability of leaves, their quality, and water chemistry are important factors explaining the differences.

\section{CONCLUSION}

Detritus based systems are ideal to test many current ecological theories. They can be studied at community, population, and auto-ecology levels. Litter decomposition is also a research field in which the knowledge of several areas of science (plant ecology, biochemistry, mycology, population ecology, and others) is needed. If organic matter breakdown is an important process in streams, factors interfering with the activities of fungi and invertebrates are likely to affect the functional process of decomposition. Therefore, decomposition rates may be used as indicators of functional status of streams, as proposed by Gessner \& Chauvet (2002).

\section{REFERENCES}

ABELHO, M. 2001. From litterfall to breakdown in streams: a review. TheScientificWorld, 1: 656-680.

ABELHO, M. \& M. A. S. GRAÇA. 1998. Litter in a temperate deciduous forest stream ecosystem. Hydrobiologia, 386: 147-152.

ABELHO, M., C. CRESSA \& M. A. S. GRAÇA. 2005. Microbial biomass, respiration and decom- 
position of Hura crepitans L. (Euphobiacea) leaves in a tropical stream. Biotropica, 37: 397-402.

AZEVEDO-PEREIRA, H., J. GONZÁLEZ \& M. A. S. GRAÇA. (2006). Life history of Lepidostoma hirtum in an Iberian stream and its role on organic matter processing. Hydrobiologia, 559: 183-192.

BÄRLOCHER, F. 2000. Water-borne conidia of aquatic hyphomycetes: seasonal and yearly patterns in Catamaran Brook, New Brunswick, Canada. Can. J. Bot., 78: 157-167.

BÄRLOCHER, F., C. CANHOTO \& M. A. S. GRAÇA. 1995. Fungal colonization of alder and eucalypt leaves in two streams in central Portugal. Arch. Hidrobiol., 133: 457-470.

BÄRLOCHER, F. \& M. A. S. GRAÇA. 2002. Exotic riparian vegetation lowers fungal diversity but not leaf decomposition in Portuguese streams. Freshwat. Biol., 47: 1123-1135.

BÄRLOCHER, F. \& C. W. PORTER. 1986. Digestive enzymes and feeding strategies of three stream invertebrates. J. N. Am. Benthol. Soc., 5: 58-66.

CALOW, P. 1975. The feeding strategies of two freshwater gastropods, Ancylus fluviatilis (Hull) and Planorbis contortus Linn.(Pulmonata) in terms of ingestion rates and absorption efficiencies. Oecologia, 20:33-49.

CANHOTO, C. 2001. Eucalyptus globulus leaves: morphological and chemical barriers to decomposition in streams. PhD Thesis, University of Coimbra, $176 \mathrm{pp}$.

CANHOTO, C., F. BÄRLOCHER \& M. A. S. GRAÇA. 2002. The effects of Eucalyptus globulus oils on fungal enzymatic activity. Arch. Hydrobiol., 154: 121-132.

CANHOTO, C. \& M. A. S. GRAÇA. 1995. Food value of introduced eucalypt leaves for a Mediterranean stream detritivore: Tipula lateralis. Freshwat. Biol., 34: 209-214.

CANHOTO, C. \& M. A. S. GRAÇA. 1996. Decomposition of Eucalyptus globulus leaves and 3 native leaf species (Alnus glutinosa, Castanea sativa and Quercus faginea) in a Portuguese low order stream. Hydrobiologia, 333: 79-85.

CANHOTO, C. \& M. A. S. GRAÇA. 1998. Leaf retention: a comparative study between stream categories and leaf types. Verh. Int. Verein. Limnol., 26: 990-993.

CANHOTO, C. \& M. A. S. GRAÇA. 1999. Leaf barriers to fungal colonization and shredders (Tipula lateralis) consumption of decomposing Eucalyptus globulus. Microb. Ecol., 37: 163-172.
CORTES, R., M. A. S. GRAÇA \& A. MONZÓN. 1994. Replacement of alder by eucalypt along two streams with different characteristics: Differences on decay rates and consequences to the system functioning. Verh. Int. Verein. Limnol., 25: 16971702.

CORTES, R., M. A. S. GRAÇA, J. VINGADA \& S. V. OLIVEIRA. 1995. Stream typology and dynamics of leaf processing. Ann. Limnol., 31: 119-131.

FEIO, M. J. \& M. A. S. GRAÇA. 2000. Food consumption by the larvae of Sericostoma vittatum (Trichoptera), an endemic species from the Iberian Peninsula. Hydrobiologia, 439: 7-11.

GESSNER, M. O. \& E. CHAUVET. 1994. Importance of stream microfungi in controlling breakdown rates of leaf litter. Ecology, 75: 1807-1817.

GESSNER, M. O. \& E. CHAUVET. 2002. A case for using litter breakdown to assess functional stream integrity. Ecol. Appl., 12: 498-510.

GONÇALVES, J. F. JR., M. A. S. GRAÇA \& M. CALLISTO. (In press). Leaf litter breakdown in 3 streams in temperate, mediterranean and tropical Cerrado climates. J. N. Am. Benthol. Soc.

GONZÁlEZ, J. M. \& M. A. S. GRAÇA. 2003. Conversion of leaf litter to secondary production by the shredder caddisfly Sericostoma vittatum. Freshwat. Biol., 48: 1578-1592.

GRAÇA, M. A. S. 1992. Starvation and food selection by stream detritivores. Ciênc. Biol. Ecol. Syst., 12: 27-35.

GRAÇA, M. A. S. 1993. Patterns and processes in detritus-based stream systems. Limnologica, 23: 107-114.

GRAÇA, M. A. S. 2001. The role of invertebrates on leaf litter decomposition in streams - A review. Int. Rev. Hydrobiol., 86: 383-393.

GRAÇA, M. A. S. \& F. BÄRLOCHER. 1998. Proteolytic gut enzymes in Tipula caloptera - interaction with phenolics. Aquat. Insect., 21: 11-18.

GRAÇA, M. A. S., C. CRESSA, M. O. GESSNER, M. J. FEIO, K. A. CALLIES \& C. BARRIOS. 2001a. Food quality, feeding preferences, survival and growth of shredders from temperate and tropical streams. Freshwat. Biol., 46: 947-957.

GRAÇA, M. A. S. \& R. FERREIRA. 1995. The ability of selected aquatic hyphomycetes and terrestrial fungi to decompose leaves in freshwater. Sydowia, 47: 167-179.

GRAÇA, M. A. S., R. C. FERREIRA \& C. N. COIMBRA. 2001b. Decomposition along a stream order gradient: the role of invertebrates and microbes. J. N. Am. Benthol. Soc., 20: 408-420. 
GRAÇA, M. A. S., L. MALTBY \& P. CALOW. 1993a. Importance of fungi in the diet of Gammarus pulex (L.) and Asellus aquaticus (L.); I Feeding strategies. Oecologia, 93: 139-144.

GRAÇA, M. A. S., L. MALTBY \& P. CALOW. 1993b. Importance of fungi in the diet of Gammarus pulex (L.) and Asellus aquaticus (L.): II Effects on growth, reproduction and physiology. Oecologia, 96: 304-309.

GRAÇA, M. A. S., L. MALTBY \& P. CALOW. 1994. Comparative ecology of Gammarus pulex (L.) and Asellus aquaticus (L.): II Fungal preferences. Hydrobiologia, 281: 163-170.

GRAÇA, M. A. S., S. Y. NEWELL \& R. T. KNEIB. 2000. Consumption rates of organic matter and fungal biomass of the Spartina alterniflora decay system by three species of saltmarsh invertebrates. Mar. Biol., 136: 281-289.

GRAÇA, M. A. S., J. POZO, C. CANHOTO \& A. ELOSEGI. 2002b. Effects of Eucalyptus plantations on detritus, decomposers and detritivores in streams. TheScientificWorld, 2: 1173-1185.

GULIS, V. \& K. SUBERKROPP. 2003. Leaf litter decomposition and microbial activity in nutrientenriched and unaltered reaches of a headwater stream. Freshwat. Biol., 48: 123-134.

HIEBER, M. \& M. O. GESSNER. 2002. Contribution of stream detrivores, fungi, and bacteria to leaf breakdown based on biomass estimates. Ecology, 83: 1026-1038.

PASCOAL, C. \& F. CASSIO. 2004. Contribution of fungi and bacteria to leaf decomposition in a polluted river. Appl. Environ. Microb., 70: 5266-5273.
PEREIRA, A. P., M. A. S. GRAÇA \& M. MOLLES. 1998. Leaf litter decomposition in relation to litter physico-chemical properties, fungal biomass, arthropod colonization, and geographical origin of plant species. Pedobiologia, 42: 316-327.

PINTO, C., J. P. SOUSA, M. A. S. GRAÇA \& M. M. GAMA. 1997. Forest soil collembola. Do tree introductions make a difference? Pedobiologia, 41: 131-138.

RICKEFS, R. E. 2000. The Economy of Nature. $5^{\text {th }}$ ed. New York: Freeman. 550 pp.

RODRIGUES A. P. L. \& M. A. S. GRAÇA. 1997. Enzymatic analysis of leaf decomposition in freshwater by selected aquatic hyphomycetes and terrestrial fungi. Sydowia, 49: 160-173.

ROLLO, C. D. \& M. D. HAWRYLUK. 1988. Compensatory scope and resource allocation in two species of aquatic snails. Ecology, 69: 146-156.

SUBERKROPP, K. 1992. Interactions with invertebrates. In: The Ecology of Aquatic Hyphomycetes. Felix Bärlocher (ed): 118-134. Ecological Studies 94, New York, Berlin: Springer-Verlag.

SUBERKROPP, K. \& E. CHAUVET. 1995. Regulation of leaf breakdown by fungi in streams: influences of water chemistry. Ecology, 76: 1433-1445.

TOWNSEND, C. R., J. L. HARPER \& M. BEGON. 2000. Essentials of Ecology. $2^{\text {nd }}$ ed. Oxford: Blackwell. 552 pp.

VITOUSEK, P. M. 1996. Biological invasions and ecosystem properties: can species make a difference? In: Ecology of Biological Invasions of North America and Hawaii: 162-176. New York, Berlin: Springer-Verlag. 